\title{
Studies on Dynamic Mechanical Properties of Silk Fibroin
}

by

\author{
Jyun Magoshi
}

(Sericultural Experiment Station, Suginamiku, Tokyo)

The dynamic and thermal properties of silk fibroin of various conformations (random coil, $\alpha$-form, and $\beta$-form) were investigated. Samples of silk fibroin films and well-oriented $\beta$-forms of degummed silk, raw silk, and silk gut were used.

The temperature dependence of dynamic modulus $\left(E^{\prime}\right)$ for random coil, $\alpha$-form, and $\beta$-form of silk fibroin film was measured. Below $100^{\circ} \mathrm{G}, E^{\prime}$ decreased with increasing temperature. This is probably due to the evaporation of water contained in the samples. Above $150^{\circ} \mathrm{C}$, $E^{\prime}$ decreased. The decrease may be caused by molecular motion of the main chains or by the partial decomposition of silk fibroin. $\quad E^{\prime}$ for silk fibroin in the random coil conformation increased around $180^{\circ} \mathrm{C}$. This increase is considered to be due to the crystallization of the silk fibroin. For the degummed silk, raw silk, and silk gut, $E^{\prime}$ decreased slowly up to about $160^{\circ} \mathrm{C}$. The loss tangent increased slowly up to about $100^{\circ} \mathrm{G}$, being due to the evaporation of water in the random coil, $\alpha$-form, and $\beta$-form samples. The random coil sample showed a dispersion peak at around $180^{\circ} \mathrm{C}$, which is caused by the crystallization of silk fibroin. The loss tangent increased in $\alpha$-form and $\beta$-form samples at $150^{\circ} \mathrm{C}$. This is caused by the molecular motion of main chains or the partial decomposition of silk fibroin. For the degummed silk, raw silk, and silk gut, a dispersion peak was observed at 265,265 , and $250^{\circ} \mathrm{C}$, respectively.

The decomposition peak in DTA curve appeared at 290,294 , and $296^{\circ} \mathrm{C}$ for the random coil, $\alpha$-form, and $\beta$-form, respectively. For the random coil, the exthothermic peak appeared at $218^{\circ} \mathrm{C}$, which is caused by $\beta$-form crystallization. The decomposition peak in the raw silk, degummed silk, and silk gut appeared at 376,393 and $310^{\circ} \mathrm{C}$, respectively.

\section{絹フィブロインの粘弾性に関する研究*}

馬越淳**

（原稿受理：1973年 8 月 31 日）

\section{1. 緒}

生体高分子である絹フィブロインの分子形態には，従来から知 られている $\alpha$ 型および $\beta$ 型の結晶変態 ${ }^{1)}$ と, 無定形である random coil 型の 3 種類があり 2 ， との 3 種類の絧フィブロインは延伸す るととにより,配向した $\beta$ 型結晶構造に転移する ${ }^{3)}$. またrandom coil 型の組フィブロインは, メタノールおよびエタノールなどの 極性をもった有機溶剂で処理すると， $\beta$ 型に転移するととがすで に知られている1).

本報において，乙れらの分子形態の異なった絹フィブロイン， すなわち random coil 型， $\alpha$ 型， $\beta$ 型および配向した $\beta$ 型の内 部構造および分子運動を解析する手段として, 動的粘弾性および 示差熱測定を行ない，組フィブロインの分子形態との関係を明ら

* 絹の構造と物性に関する研究 第 5 報 Studies on Structure and Physical Properties of Silk (5) とする。

** 農林省亘系試験場 東京都杉並区和田 3-55-30
かにしたので，乙こに報告する.

\section{2. 実験}

\section{1 試料作製}

試料としてつぎの 7 種の絹フィブロインを作製した，1）家虫 （日124号×支124号）の熟虫体内の中部絹糸腺後区から採取した 液状組フィブロイン $\left(\right.$ 濃度 $\left.25 \%{ }^{2}\right)$ を純水で希䣋し，その水溶液 （濃度 $0.8 \%$ ）をポリエチレンフイルム上で， $20{ }^{\circ} \mathrm{C}$ ，関係湿度 $65 \%$ の温調室にて送風乾燥して得られた組フィブロインフイルム（以 下との試料を Sample-(1) という). 2) Sample-(1) メタノー ル中 $\left(20^{\circ} \mathrm{C}\right)$ 亿 時間浸漬したのち, $20^{\circ} \mathrm{C}$, 関係湿度 $65 \%$ で乾燥 して得られた綃フィブロインフイルム（Sample-(2)）．3)液状絧 フィブロイン（濃度 $25 \%$ ）をポリエチレンフイルム上で, $20^{\circ} \mathrm{C}$, 関係湿度 $65 \%$ の温調室で乾燥して得られた絹フィブロインフィル

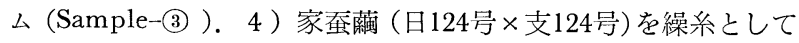
得られた生系 (Sample-(4))。 5 ) Sample-(4)からセリシンを除 
Table 1. Conformation, moisture regain and density of each specimen of silk fibroin.

\begin{tabular}{c|ccccccc}
\hline Sample & Sample-1 & Sample-2 & Sample-3 & Sample-4 & Sample-5 & Sample-6 & Sample-7 \\
\hline \multirow{2}{*}{ Name } & $\begin{array}{c}\text { Silk fibroin } \\
\text { film }\end{array}$ & $\begin{array}{c}\text { Silk fibroin } \\
\text { film }\end{array}$ & $\begin{array}{c}\text { Silk fibroin } \\
\text { film }\end{array}$ & Raw Silk & $\begin{array}{c}\text { Degummed } \\
\text { Silk }\end{array}$ & $\begin{array}{c}\text { Regenerated } \\
\text { Silk fibroin } \\
\text { film }\end{array}$ & Silk Gut \\
Conformation & random coil & $\beta$-form & $\alpha$-form & $\beta$-form & $\beta$-form & random coil & $\beta$-form \\
Density & 1.310 & 1.348 & 1.345 & 1.365 & 1.353 & 1.308 & 1.352 \\
Moisture* & $10 \%$ & $8 \%$ & $8 \%$ & $11 \%$ & $10 \%$ & $10 \%$ & $6 \%$ \\
Composition & fibroin & fibroin & fibroin & $\begin{array}{c}\text { fibroin }+ \text { sericin } \\
(76 \%)\end{array}$ & fibroin & fibroin & fibroin \\
\hline
\end{tabular}

* at $20^{\circ} \mathrm{C}, 65 \%$ r.h.

去した精練糸（Sample-(5)）６６） Sample-(5) を $20^{\circ} \mathrm{C}$ で臭化り チウム水溶液に溶解し，七ロハンチューブを用いて純水中で 2 日 間透析し，再生綃フィブロイン水溶液を作製し，乙の水溶液をポ リエチレンフイルム上で， $20^{\circ} \mathrm{C}$, 関係湿度 $65 \%$ の温調室で送風 乾燥して得られた再生組フィブロインフィルム(Sample-(6)７） 熟㝠体内から取り出した絹糸線を $0{ }^{\circ} \mathrm{C}$ 水水中で15倍延伸し，セ リシンを除いて得られた絧フィブロインガット (Sample-( 7) ). これらの7 種の絧フイブロインを試料として用いた.

\section{2 実験方法}

絧フィブロインの動的粘弹性の測定には, 東洋測器製の直読式 動的粘弾性測定装置 (VIBRON-II) を使用し, 動的ヤング率 $\left(E^{\prime}\right)$ と $\tan \delta$ を周波数 $110 \mathrm{~Hz}$, 昇温速度 $3^{\circ} \mathrm{C} / \mathrm{min}$, 測定温度範囲 $0 \sim$ $270^{\circ} \mathrm{C}$ で行なった。示差熱測定は, 理学電機製の標準型測定装置 を用いて, 絹フィブロインの水分の蒸発および分解ピーク温度を 求めた。昇温速度は $10^{\circ} \mathrm{C} / \mathrm{min}$, 標準試料 $\alpha$ ーアルミナを使用した。 $\mathrm{X}$ 線回折像は理学電機製のX線回折装置で, $20 \mathrm{~mA}, 35 \mathrm{KV}, \mathrm{CuK}_{\alpha}$ 線を用い， Ni フィルターを通して， ワイゼンベルグカメラで撮 影した．赤外吸収スペクトルは日本分光工業の IR-G 型の赤外分 光光度計で測定した，密度は四塩化炭素一トルエン系を用い，密 度勾配管法で $30^{\circ} \mathrm{C}\left( \pm 0.1^{\circ} \mathrm{C}\right)$ 亿て測定し試料中の水分を考慮し て求めた。

動的粘弾性測定および示差熱測定は $20^{\circ} \mathrm{C}, 65 \%$ r.h. の恒温室 にて, 試料を 2 日間放置して, 実験を行なった。

\section{3 試料の分子形態および含水率}

作製した試料の分子形態は，X線回折像および赤外吸収スペク トルの結果から, Table 1. 亿示したように, Sample-(1) は random coil 型, Sample-(2) は無配向の $\beta$ 型, Sample-(3) は無配向 の $\alpha$ 型，Sample-(4) は配向した $\beta$ 型（ただしセりシンが24\%含 まれている). Sample-(5) は配向した $\beta$ 型, Sample-(6) は random coil 型, Sample-(7) は配向した $\beta$ 型であるととがわかっ $た^{1) \sim 3)}$ random coil 型, 無配向の $\alpha$ 型および $\beta$ 型, 配向した $\beta$ 型のX線回折像を Fig. 1 亿示す. Sample (1)-(7) の含水率および 密度については, Table 1. にあわせて示した。生系の密度が他 の試料に比べて大きいのは，試料中に含まれるセリシンによるも ので, セリシンの密度がフィブロインのそれに比べて高いてとに 起因する ${ }^{4)}$.

\section{3. 実 験 結 果}

\section{1 絹フィブロインフイルムの動的粘弾性}

random coil 型の絹フィブロインフィルム (Sample-(1) およ び再生絹フィブロインフィルム (Sample-(6) の動的ヤング率と $\tan \delta$ の温度依存性を Fig. 2 亿示す. 絹フィブロインフィルム

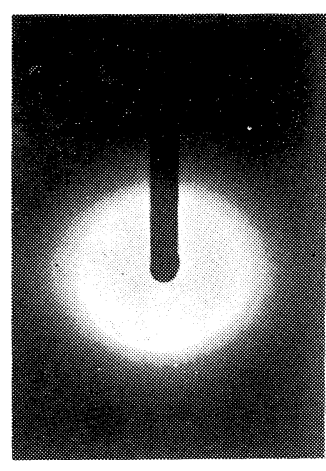

a) Random coil

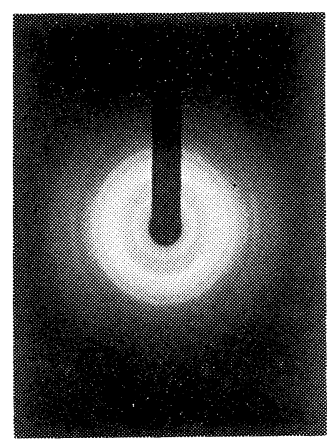

c) $\alpha$-form

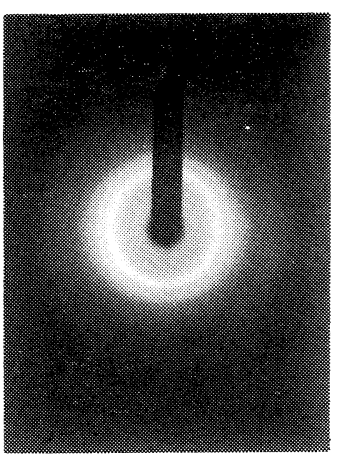

b) $\beta$-form

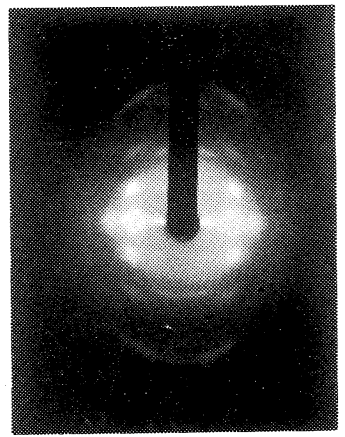

d) Well-oriented $\beta$-form (degummed silk)
Fig. 1. X-ray diffraction patterns of random coil, $\alpha$-form, and $\beta$-form of silk fibroin film and well-oriented $\beta$-form (degummed silk).

(Sample-(1)）の動的ヤング率は，100 $\mathrm{C}$ 付近までわずが低下し， $100 \sim 140^{\circ} \mathrm{C}$ の範囲ではほぼ一定である. $140^{\circ} \mathrm{C}$ をすぎると急激に 低下し， $180^{\circ} \mathrm{C}$ 付近からまた急激に上昇するが，190 Cから再び低 下するととを観察した． Sample-(1)の $\tan \delta$ は温度上昇ととも に徐々に大きくなり, $140^{\circ} \mathrm{C}$ 付近から急激に上昇する. そして 170 〜 $180^{\circ} \mathrm{C}$ 亿分散ピークが現われ， $190^{\circ} \mathrm{C}$ から再び急上昇する. 再生 組フィブロインフイルム (Sample-6) の動的ヤング率および $\tan \delta$ は, Sample-(1) と同様な挙動を示すが, 動的ヤング率と $\tan \delta$ が急激に変化する温度が組フィブロインフィルム (Sample(1)）のそれに比べて若干低温度側から現われはじめるととを観察 した.

$\alpha$ 型（Sample-(3)）および $\beta$ 型(Sample-(2) の無配向絧フィブ ロインフイルムの動的ヤング率と $\tan \delta$ を Fig. 2 亿併せて示す. 両者のフィブロインフィルムの動的ヤング率は $100^{\circ} \mathrm{C}$ 付近までわ ずかに低下し， $100 \sim 150^{\circ} \mathrm{C}$ の範囲ではほぼ一定で, $150^{\circ} \mathrm{C}$ 付近か ら急激に減少する。 $150^{\circ} \mathrm{C}$ までの温度範囲におけるてれらの挙動 


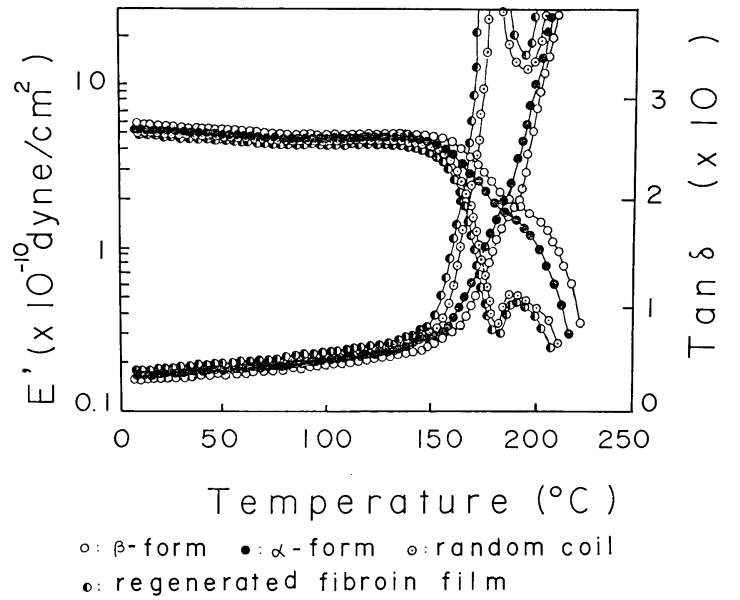

Fig. 2. Temperature dependence of $E^{\prime}$ and loss tangent for films of random coil, $\alpha$-form, $\beta$-form, and regenerated silk fibroin.

は random coil 型と同様であるが，動的ヤング率は全般的にわ ずかに大きい. 180 $190^{\circ} \mathrm{C}$ の温度範囲で random coil 型の試料 に現われた動的ャング率の上昇は認められなかったが，わずかに ショルダーが認められた. Sample-(2) と Sample-(3)の $\alpha$ 型およ び $\beta$ 型フィルムの $\tan \delta$ の温度依存性は， $150^{\circ} \mathrm{C}$ ま゙徐々に増加 し， $160^{\circ} \mathrm{C}$ 付近から急激に上昇し，180 $190^{\circ} \mathrm{C}$ において random coil 型で見られた分散ピークは認められず，ショルダーだけを観 測した. $\alpha$ 型と $\beta$ 型のフィルムの動的粘弾性の温度依存性にはほ とんど相違は認められないが， $160^{\circ} \mathrm{C}$ 付近で $\alpha$ 型フイルムの方が わずかに低温側から変化を示した。

\section{2 配向した $\beta$ 型絹フィブロインの動的粘弾性}

生糸 (Sample-(4)), 精練糸 (Sample-(5)), 絹フィブロインガ ット (Sample-(7) の動的ヤング率および $\tan \delta$ の温度依存性は Fig. 3 亿示すとおりで, 動的ヤング率は $100^{\circ} \mathrm{C}$ まで徐々に減少す る. $100 〜 160^{\circ} \mathrm{C}$ までほぼ一定で， $160^{\circ} \mathrm{C}$ をすぎると再び徐々に減 少し, $200^{\circ} \mathrm{C}$ 前後から急激に低下する．低下の割合は絧フィブロ インガット, 生系, 精練系の順に少なくなっている. 上述の三つ の試料の $\tan \delta$ は, $0 \sim 150^{\circ} \mathrm{C}$ まで徐々に増加し， $170^{\circ} \mathrm{C}$ 付近から 急上昇する．組フィブロインガット (Sample-(7) では $250^{\circ} \mathrm{C} に$

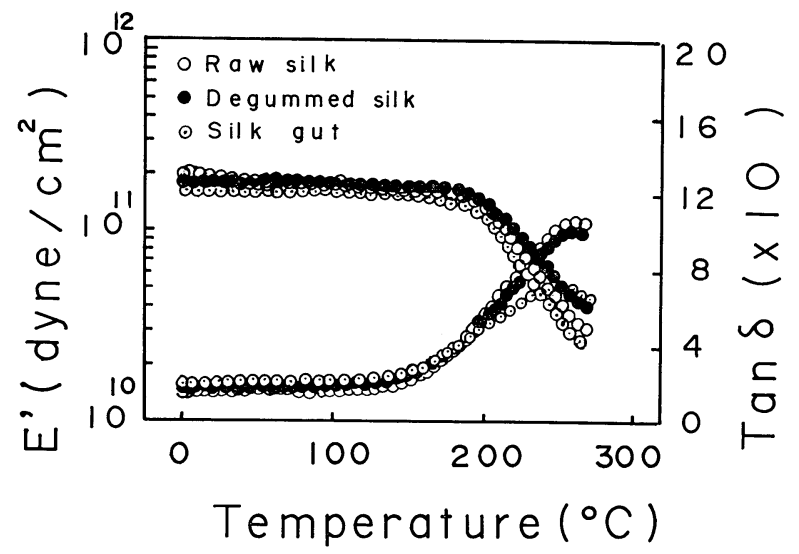

Fig. 3. Temperature dependence of $E^{\prime}$ and loss tangent for raw silk, degummed silk and silk gut.
分散ピークが観察され，生糸，精練糸では $265^{\circ} \mathrm{C}$ 亿分散ピークの 最大值が測定された。

$20^{\circ} \mathrm{C}$ における三つの試料（Sample-(4)(5)(7)）の動的ャング率は, 無配向の $\alpha$ 型， $\beta$ 型および random coil 型の動的ヤング率に比 べて，1 ケ夕高い值を示したが， $\tan \delta$ はほぼ同じ值であった. 生系, 精練糸, 絹フィブロインガットの動的ヤング率および $\tan \delta$ は，それぞれ $1.65 \times 10^{11}, 1.65 \times 10^{11}, 1.54 \times 10^{11} \mathrm{dyne} / \mathrm{cm}^{2}$ および 0.018，0.016，0.020であった.

\section{3 絹フィブロインフイルムの DTA 曲線}

random coil 型 (Sample-(1)), $\alpha$ 型 (Sample-(2)), および $\beta$ 型 (Sample-(2) の絹フィブロインフィルムのDTA 曲線をFig. 4 に示す．分子形態の異なった 3 種の絹フィブロインフィルムの DTA 曲線には $100^{\circ} \mathrm{C}$ 付近にブロードな吸熱ピークが認められ, これは絹フィブロインフィルム内に含まれる水分の蒸発によるも のと推定されたので, 試料の重量減少を測定するととによってそ れを確かめた. random coil 型（Sample-(1)）のフイルムには $218^{\circ} \mathrm{C}$ に発熱ピークか認められた。 このピークは $\alpha$ 型および $\beta$ 型 のフイルムでは認められなかった。 との発熱ピークは絹フイブロ インの結晶化によって現われたものと考光，ての発熱ピーク温度 の前後でX線回折像を観察したととろ， $180^{\circ} \mathrm{C} \sim 190^{\circ} \mathrm{C}$ では random coil 特有の八ロー図形を示し, $220^{\circ} \mathrm{C}$ にいては $\beta$ 型の図形 が得られたてとから，乙の発熱ピークは random coil 型の絹フ ィブロインが $\beta$ 型に結晶化したものであるてとが確かめられた。

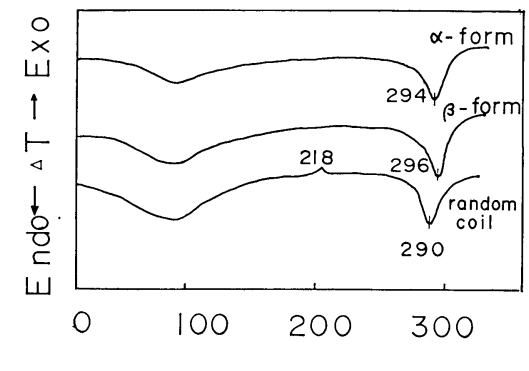

Temperature $\left({ }^{\circ} \mathrm{C}\right)$

Fig. 4. DTA thermograms of random coil, $\alpha$-form, and $\beta$-form of silk fibroin film.

random coil 型 (Sample-(1)), $\alpha$ 型 (Sample-(2)), $\beta$ 型 (Sample-(3) の組フィブロインフィルムは，いずれも $300^{\circ} \mathrm{C}$ 前 後に吸熱ピークがあらわれ，random coil では $290^{\circ} \mathrm{C} ， \alpha$ 型では $294^{\circ} \mathrm{C}, \beta$ 型では $296^{\circ} \mathrm{C}$ に吸熱ピークの最大值があった。 この吸 熱ピークは試料の炭化が絹フィブロインの分解ピークと考えられ る. 分解ピーク温度の差から random coil 型, $\alpha$ 型, $\beta$ 型の順 に熱的に安定であるととが確かめられた。

\section{4 配向した $\beta$ 型の DTA 曲線}

精練糸 (Sample-(5)), 生糸 (Sample-(4)), 絹フィブロインガ ット (Sample-(7)) の DTA 曲線を Fig. 5 と示すと， 3 種類と も $60 \sim 100^{\circ} \mathrm{C}$ 付近にブロードな吸熱ピークを示し，とのピークは 試料内に含まれる水分の蒸発に起因するものであると考えられ る. 精練糸, 生糸では $260^{\circ} \mathrm{C}$ 付近から発熱があらわれ，乙の温度 から試料のいちじるしい黄变が始まるととを考えると, 絹フィブ ロインの酸化か㴌ったものと思われる. 配向した $\beta$ 型の試料には 高温度側に吸熱ピークがあり, その温度は精練糸で $393^{\circ} \mathrm{C}$, 生糸 
で $376^{\circ} \mathrm{C}$ ，絹フィブロインガットで $310^{\circ} \mathrm{C}$ であった

絹フィブロインの高温側つ吸熱ピーク, すなわち分解ピーク温 度は組フィブロインの分子形態に依存し, 無配向試料 (Sample(1), Sample-(2), Sample-(3) と配向試料 (Sample-(4), Sample(5), Sample-(7)）とでは配向試料の方が高温側にあった. 配向試 料のなかでも, 生系・精練糸の方が組フィブロインガットに比べ て高温側にあった．てれらの分解ピーク温度と分子形態による相 違については，次節の考察において記述する.

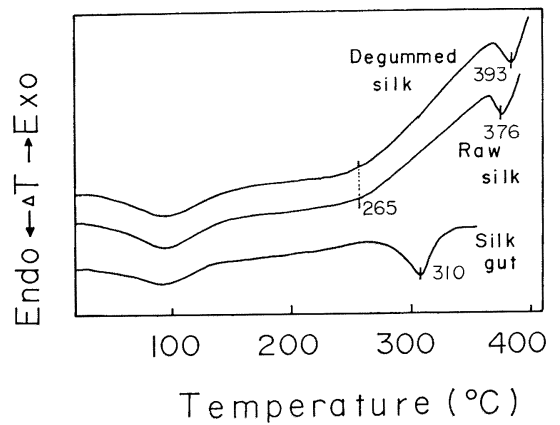

Fig. 5. DTA thermograms of degummed silk, raw silk, and silk gut.

\section{4. 考}

\section{察}

絹フィブロインの分子運動は，種々の条件によって異なってお り, たとえば, 分子形態の相違 ${ }^{6)}$, 結晶化度 ${ }^{11)}$, 配向性 ${ }^{5)}$, 水分の存 在 $^{6)}$ ，セリシンの有無などによって影響される．水分の影響につ いては，Table 1 に示すように各試料とも水分を含んでいるた めに, $100^{\circ} \mathrm{C}$ までの動的ャング率の減少および $\tan \delta$ の増加の原 因となっていると考えられる。すなわち各試料の $100^{\circ} \mathrm{C}$ までの動 的ヤング率の低下と $\tan \delta$ の昇は, 試料中に含まれている水分 の蒸発によるものであろう。すなわち, Fig. 4 および 5 の DTA の結果からも明らかなように， $100^{\circ} \mathrm{C}$ 付近にブロードな吸熱ピー クが現われ，乙れが水分の蒸発に起因していることから，絹フィ ブロイン分子間，および非晶部分に入っている水分子が蒸発し， 水分子で形成されている水素結合, 疎水結合が切断するてとによ って，絧フィブロインの分子間結合がルーズになるために，動的 ヤング率が低下したものと考光られる。また，乙れらの挙動をさ らに確かめるために, 次のような実験を行なった。すなわち, 組 フィブロインの試料（Sample-(1)，(2)，(4)，(5)，(7)）を $105^{\circ} \mathrm{C}$ で 2 時間乾燥し，空気のかわいた実験室で動的ヤング率を測定する と，100 $\mathrm{C}$ までの温度範囲で，動的ャング率の低下はほとんど認 められなかった，とのととによっても，100 C までの動的ャング 率および $\tan \delta$ の変化は水分の蒸発によることが確かめられた.

次に絹フィブロインの分子形態の相違による分子運動の影響は， $140^{\circ} \mathrm{C}$ 以上であらわれる. random coil 型絹フィブロイン(Sample(1), (6))の動的ヤング率および $\tan \delta$ が $140^{\circ} \mathrm{C}$ 付近から急激に変化 する挙動は, 非晶状態にある絹フィブロイン分子鎖の熱運動と同 時に，分子鎖の一部の分解も考えられる. そてで絹フィブロイン の分解であることを確かめるために, 恒温槽を取りつけた顕微鏡 で組フィブロインフィルム（Sample-(1)，(2)，(3)）の表面を観察 すると， $140 \sim 150^{\circ} \mathrm{C}$ 付近から試料の黄変が始まる，乙のととから $140^{\circ} \mathrm{C}$ 付近から一部分解が生じるととがわかった。 $\alpha$ 型 (Sample-
(3) と $\beta$ 型 (Sample-(2) ) の綃フィブロインフイルムの動的ヤン グ率は， $150^{\circ} \mathrm{C}$ 付近から低下するが，乙の低下は random coil 型 に比べて緩慢である。乙の挙動は， $\alpha$ 型および $\beta$ 型フィブロイン 内部に存在する非晶部の熱運動性の相違によると考えられる．密 度法によって求めた $\alpha$ 型および $\beta$ 型フィブロインの結晶化度はそ れでれ，28\%および30\%である7). このととにより絧フィブロイ

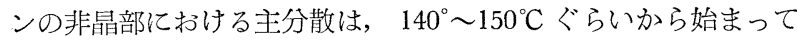
いると推定される.

random coil 型絹フィブロインフイルムでは， $170 \sim 190^{\circ} \mathrm{C}$ の範 囲で, $\tan \delta$ の分散ピークが現われ, 動的ヤング率は上昇するが, $\alpha$ 型および $\beta$ 型組フィブロインでは両者ともショールダーとして だけしかあらわれないことから，乙の分散は無定形高分子にあら われる主分散と同様であると考えられるが，ての温度範囲で誘電 分散および示差熱測定および熱膨脹（温度変化に対する試料の長 さ変化）なぞの実験を行なうと ${ }^{8) 11)}$ ，誘電分散において，random coil 型絹フィブロイン $(\text { Sample-(6) })^{6)}$ で $160^{\circ} \mathrm{C} \sim 180^{\circ} \mathrm{C}$ に分散ピ 一クが現われ，乙の分散ピークには周波数依存性がなく，周波数 が高くなると分散ピークの大きさが低下するとと, 示差熱測定に おいて， $180^{\circ} \mathrm{C}$ 付近にかすかに吸熱ピークが現われること ${ }^{9)}$ ，熱 膨脹は $160^{\circ} \mathrm{C} \sim 180^{\circ} \mathrm{C}$ まで急激に増大するととなどから考えあわせ て，無定形域の主鎖のセグメント運動だけでなく絧フィブロイン の構造変化に対応する分散と思われる. また綃フィブロインの構 造変化は，分子間の強固な水素結合が切断し，そのあとまた再結 合したものと考光られる. そてで $160^{\circ} \mathrm{C} \sim 180^{\circ} \mathrm{C}$ 分散ピークと， $180^{\circ} \mathrm{C} \sim 190^{\circ} \mathrm{C}$ の動的ヤング率の上昇と， $218^{\circ} \mathrm{C}$ 亿あらわれる発熱 ピークについては, $160^{\circ} \mathrm{C} \sim 180^{\circ} \mathrm{C}$ で非晶部の主分散すなわち無定 形域における主鎖のセグメント運動がおてり，その過程で強固に 結合している分子間の水素結合が切断し， $180^{\circ} \mathrm{C} \sim 190^{\circ} \mathrm{C}$ で再結合 化がおこるために，動的ヤングが上昇するものと考えられる．ま たその付近の温度から絹フィブロインの結晶化が始まり, 発熱ピ 一クが出現したものと思われる.

$\alpha$ 型および $\beta$ 型の絹フィブロインフィルムの $160^{\circ} \mathrm{C} \sim 190^{\circ} \mathrm{C}$ 付近 の挙動は, $70 \%$ 前後も非晶部が残っているにもかかわらず, $180^{\circ} \mathrm{C}$ 付近にショルダーがあらわれるだけであった。この理由として, 合成高分子の二相系における明確な挙動は認められず，絹フィブ ロインの場合には，18種類のアミノ酸で構成され ${ }^{1)}$, 結晶部を作 っているグリシン，アラニンと残りのアミノ酸で構成されてい る非晶部との複雑な構造に由来するもので, 単に二相系として分 離できないととである．従っててのような考えでショルダー部分 は非晶部と思われる無定形領域の主鎖のセグメント運動で生じた ものと思われる.

配向性の影響については, 配向した $\beta$ 型組フィブロイン (Sample-(4), (5), (7)）の動的ヤング率および $\tan \delta$ の $100^{\circ} \mathrm{C}$ までの温 度依存性は, random coil 型, $\alpha$ 型, $\beta$ 型組フィブロインフイル 么と同様であるが， $150^{\circ} \mathrm{C}$ 以上で無配向の random coil, $\alpha, \beta$ 型 絧フィブロインフイルムのように急激な変化は認められないが, 徐々に増減しているてとが Fig. 3 から明らかであり, 配向の効果 があらわれている。配向した $\beta$ 型では $260^{\circ} \mathrm{C}$ 前後に分散ピークが ある. この分散ピークは絹フィブロインの結晶の緩和現象で, 普 通の高分子にあらわれる挙動とは異なり，組フィブロインの分子 間結合の切断および分子鎖の一部分の酸化，分解のためにおきる 現象であり，DTA の結果で発熱が $260^{\circ} \mathrm{C}$ 付近から現われ始める 
のと対応するものである. 絹フィブロインガットでは $250^{\circ} \mathrm{C}$, 生糸, 精練糸では $260^{\circ} \mathrm{C}$ 付近にあらわれる。乙の原因は配向性と結晶化

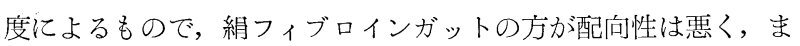
た結晶化度も低い ${ }^{12)}$.

次に random coil 型， $\alpha$ 型， $\beta$ 型および配向した $\beta$ 型絧フィ ブロイン分解ピーク温度であるが， random coil 型のピークが一 番低く, 配向した $\beta$ 型が一番高い. 乙れは, random coil 型が一 番熱に不安定であり， $\alpha$ 型, $\beta$ 型の順に安定であり,さらに $\alpha$ 型お よび $\beta$ 型絹フィブロインには $30 \%$ 前後の結晶が存在し ${ }^{2)}$, その結 晶のために高温まで崩壊しないためと考えられる， $\alpha$ 型の組フィ ブロインフイルムの DTA 曲線において, 著者 ${ }^{5}$ および平林ら ${ }^{10)}$ が報告した $270^{\circ} \mathrm{C} の$ 吸熱ピークは本実験では認められず， $294^{\circ} \mathrm{C}$ しか吸熱ピークがあらわれなかったととは， $\alpha$ 型試料の作製条件 が異なっているためであろう。亘体内の絹系腺を取り出し， $2{ }^{\circ} \mathrm{C}$

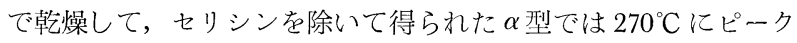
があらわれるが, 絹糸腺からセリシンを除いて, 濃度 $25 \%$ の絧フ イブロイン水溶液を $20^{\circ} \mathrm{C}$ で乾燥して得られたフイルムではてのピ 一クが現われないのは, 安定な $\alpha$ 型で結晶化したためであると考 えられる.

配向した $\beta$ 型 (Sample-4), (5), (7)）の分解ピーク温度は $310^{\circ} \mathrm{C}$ $\sim 393^{\circ} \mathrm{C}$ で, 絹フィブロインガットでは $310^{\circ} \mathrm{C}$, 精練糸で $393^{\circ} \mathrm{C}$, 生 糸で $376{ }^{\circ} \mathrm{C}$ 亿分解ピークがある. 組フィブロインガットの分解ピ ークが $310^{\circ} \mathrm{C}$ と非常に低い温度にあらわれる原因について，以下 のように考えた。 絹フィブロインガットでは $310^{\circ} \mathrm{C}$ 以外に $400^{\circ} \mathrm{C}$ 付近 ${ }^{11)}$ そ吸熱ピークがあらわれる. しかし生系, 精練糸では

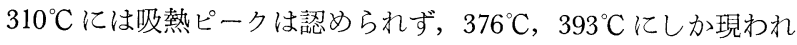
ない. $310^{\circ} \mathrm{C}$ の吸熱ピークは配向度が増加するにしたがって高温 側に移行するが5) $400^{\circ} \mathrm{C}$ 付近の吸熱ピークには変化がない. 生系, 精練糸の場合には，低温側の吸熱ピークと高温側の吸熱ピークが かさなったものと考えられ，綟フィブロインガットの場合，配向 性の悪いととによって ${ }^{12)}$ ，二つのピークに分離したものと考えら れる.この二つの吸熱ピークの出現については目下さらに検討中 である。

\section{5. 結論}

以上の実験結果から次のようなととが明らかとなった。

分子形態の異なった組フィブロインの動的粘弾性の温度依存性 は, random coil 型, $\alpha$ 型, $\beta$ 型および配向した $\beta$ 型絧フィブロ インでそれぞれ異なっていた. random coil 型, $\alpha$ 型， $\beta$ 型，お よび配向した $\beta$ 型絧フィブロインの $100^{\circ} \mathrm{C}$ までの挙動は, 水分の 蒸発による水素結合の切断之蹯水性結合の切断に関係し, DTA 曲線で $100^{\circ} \mathrm{C}$ 付近にあらわれる吸熱ピークともよく刘応する. random coil 型絹フィブロインフィルムにおいて, $180^{\circ} \mathrm{C}$ 近辺に
分散ピークが認められたが, $\alpha$ 型 $\beta$, 型組フィブロインではショー ルダーだけが現われた. random coil 型にみられる $180^{\circ} \mathrm{C}$ 近辺 の分散ピークは，無定形の主分散のほかに組フィブロイン分子間 にある強固な水素結合の切断による分散が重ったものと考えられ る.さらに $190^{\circ} \mathrm{C}$ 付近の動的ヤング率の上昇は, random coil 型 絧フィブロインフィルムに特有のもので, 絹フィブロイン分子間 の再結合によって生じたものと思われる.配向した $\beta$ 型には $250^{\circ} \mathrm{C}$ $\sim 260^{\circ} \mathrm{C}$ 亿分散ピークが認められ, 絹フィブロイン結晶の緩和現象 か認められた. また配向した $\beta$ 型の動的ヤング率は, 無配向試料 のそれに比べで 1 ケタ高い值を示した.

DTA 曲線には $100^{\circ} \mathrm{C}$ 付近に吸熱ピークがあった. また random coil 型綃フィブロインフィルムには $218^{\circ} \mathrm{C}$ に発熱ピークがあり, この発熱ピークは random coil 型組フィブロインフイルム内で の結晶化によるものでることが，X線回折像の結果から確認され た. random coil 型, $\alpha$ 型および $\beta$ 型の分解ピーク温度はそれぞ れ 290, 294 および $296^{\circ} \mathrm{C}$ であった。

配向した $\beta$ 型である精練糸, 生糸, および絧フィブロインガッ トの DTA 曲線における分解ピーク温度はそれぞれ 393，376 お よび $310^{\circ} \mathrm{C}$ であり, 無配向試料の分解温度より高温側にあるとと がわかった。

終りにあたって, 本研究を行なうにあたってで指導にあずかっ た東京大学宇宙研究所神戸博太郎教授, 大阪大学工学部笠井暢民 教授, 大阪大学蛋白質研究所長角戸正夫教授に深く感謝する.

\section{6. 文献}

1) 清水正德：蛋白質化学，5（1958）; 日龺雑，20 155(1951).

Kratky O. E. Schanenstein ; Discussion of the Faraday Soc., 11, 171 (1951).

2）馬越 淳, 笠井暢民, 角戸正夫 : 高化 32,649（1973）.

3) R.E. Marsh, R.B.Corey, L. Pauling ; Biochemical et Biophysical Acta 16, 1 (1955).

4）鈴木三郎：生糸の品質と織物（木暮槙太編）186（1964）.

5) 馬越 淳 : 材料, 22, 499 (1973).

6）馬越 淳: 第22回高分子年次大会講演要旨集, 85 (1973).

7) Magoshi, J., N. Kasai, M. Kakudo ; Rept. Progr. Polym. Phys. Japan, 15, 599 (1972).

8）馬越 淳: 第18回高分子年次大会講演要旨集, 350 (1969).

9) Magoshi, J., N. Kasai, M. Kakudo ; Rept. Progr. Polym. Phys. Japan, 15, 603 (1972).

10) 平林 㳊, 石川 博ら : 繊学誌, 28, 99 (1972).

11）馬越 淳：第19回高分子年次大会講演要集, 344 (1970); 高 化 (投稿中).

12）石川 博: 絧糸の構造, 396 (1955). 